\title{
THE EFFECT OF FEEDING SOYBEAN AND CORN FREE DIETS ON THE PERFORMANCE OF TURKEY POULTS TO EIGHT WEEKS OF AGE
}

\author{
K. M. Sulaiman ${ }^{1}$ and J. C. Hermes*
}

Department of Animal and Rangeland Sciences, Oregon State University Corvallis Oregon

${ }^{1}$ Current address: Department of Animal Production, University of Duhok, Duhok, Iraq

Email: james.hermes@oregonstate.edu, ${ }^{1}$ Email: Kurdman.sulaiman@uod.ac

Primary Audience: Extension Specialists, Feed Producers, Organic Poultry Producers

*To whom correspondence should be addressed.

(Received 18/10/2016, Accepted 15/3/2017)

\section{SUMMARY}

$\mathrm{I}$ $\mathrm{n}$ recent years, small poultry producers have been interested in finding alternatives for corn and soybean meal for a variety of reasons. Perceived health concerns related to genetically modified organism (GMO) status are the primary considerations behind this trend. Secondly, the recent high price of corn and soybean and their unavailability locally in the Pacific Northwest are other reasons to identify alternative feed ingredients. For these reasons, an experiment was performed to identify the feasibility of including locally grown alternative feed ingredients in a GMO free starter-grower turkey rations. The experiment compared the growth rates and feed conversions of broad breasted white turkeys fed either a corn based -soybean free and a wheat based (corn-soybean free) to a control (corn-soybean based) diets. Day old turkey poults were randomly assigned to one of the three diets. Body weights, feed conversion, and mortality were determined at two, four, six and, eight weeks of age. The final body weights of poults fed the control diet were significantly $(\mathrm{P}=0.001)$ higher than those fed either the corn based-soybean free or wheat based (corn-soybean free) diets. Body weights of birds fed the corn based-soybean free and wheat based (corn-soybean free) diets, $3.1 \mathrm{~kg}$ and $3.2 \mathrm{~kg}$, respectively were not different. Feed efficiency was not different among the three dietary treatments. Excluding soybean from the diets decreased growth rates in turkey poults but did not affect feed conversion.

Keywords: Poults, Soybean Free, Corn Free, Diets

\section{INTRODUCTION}

In recent years, small flock producers in the Pacific Northwest have been interested in identifying alternatives for corn and soybean meal for a variety of reasons. Perceived health concerns are the primary consideration behind this trend. Today, most soybean and corn produced in the US are genetically modified organisms (GMO). The genetics of these feed ingredients have been altered by using genetic engineering techniques, developed in the 1980's and 90's, which allow plant gene transfers from one organism into another, thereby conferring resistance to herbicides, pests, and/or diseases while resulting in higher crop yields (Key et al., 2008, Kruft, 2001 and Swanson, 2013). In recent years the worldwide cultivation of these genetically modified plants has increased with GMO derived soybean worldwide at $77 \%$ of all that is produced (GMO Compass, 2010), while in the United States the level is 93\% (United States Department of Agriculture 2013). In addition, corn grown in the United States, is 85\% GMO derived (United States Department of Agriculture, 2013).

The subject of GMOs is highly controversial. Some studies, dealing with health implications and safety issues associated with GMO foods in the human diet have been published. Some of these studies concluded that there was no harm or risk associated with the consumption of foods derived from GMO crops (Aeschbacher et al., 2005, Taylor et al., 2003, Taylor et al., 2007, Cromwell et al., 2002 and Jennings et al. 2003), while others reported contradictory results and have raised some concerns (Nordlee et al., 1996, Vecchio et al. 2009 and Leu (2012). 


\section{Sulaiman and Hermes}

The recent high price of corn and soybean is another consideration behind the trend to seek alternatives to corn and soybean. Historically, feed costs have represented 70-75\% of the cost of poultry production, which has a major role in determining the profitability of a poultry enterprise. With the use of corn in ethanol, demand has increased. In 2011, about $27.5 \%$ of U.S corn was used in ethanol production (National Corn Growers Association 2012), and as a result, the price of corn has risen sharply in recent years.

Alternative ingredients in poultry diets include cereal grains, (such as wheat, oats, and barley); legume grains, (such as peas, lentils, chickpea, and dry beans); and other non-cereal grain alternatives such as canola and camelina.

Legumes are mostly used as substitutes for soybean in poultry diets. Legume seeds are high in protein; having more than twice the protein as most cereal grains and are also a good dietary energy source. Chick pea an important grain legume in world agriculture is widely consumed by humans, due to its nutritional and high protein contents. It is also used as a source of protein in animal diets replacing some of the soybean used in formulated diets. The protein content of chickpeas ranges from $18-24 \%$ DM. Inclusion of chickpea into the rations of poultry has been studied with a general consensus for maximum inclusion of 10\% (Algam et al. 2013, Algam et al. 2012 and Torki and Karimi 2007).

Lentils are an inexpensive source of protein in the diets of people in developing countries. Lentil scan also substitute for a portion of soybean bean meal in animal diets. The protein content of lentils is between 23.9 to $25 \%$, with a fat content of about $4.3 \%$ (Akmal Khan et al. 1987).

Canola, while not a legume, is a non-cereal grain that can replace a portion of soybean bean meal in poultry diets. The protein content of canola meal is approximately 36.5\% (Spragg and Mailer, 2007). Canola meal could be used up to $10 \%$ of the broiler diets during the starter phases (Payvastagan et al., 2012) While in Japanese quail diets, canola meal could be used up to $15 \%$ without a negative effect on body weight gain (Hameed et al., 2002).

A feeding experiment was performed to determine the feasibility of substituting Pacific Northwest grown alternative feed ingredients, lentils, chickpeas, and canola, in turkey diets to 8 weeks of age, to determine whether their productivity is comparable to a typical corn/soybean-based starter-grower diet.

\section{MATERIALS AND METHODS}

Research protocols were reviewed and approved by the Oregon State University Animal Care and Use Committee (IACUC).

\section{Birds and Housing}

One hundred and seventeen straight-run Nicholas 500 day-old poults were obtained from a local commercial hatchery. The poults were randomly assigned to one of three dietary treatment group search with 13 poults in each of three replicate groups.

The research facility was an insulated enclosed building with cement floors covered with about $4 \mathrm{~cm}$ of wood shavings as bedding. Additional wood shavings were added when required during the experiment. Each pen measured $3.9 \mathrm{~m}$. by $3 \mathrm{~m}$ and heat was provided by one 250 watt infrared bulb. Pen temperatures were kept between $25-21^{\circ} \mathrm{C}$ and ventilation was provided by exhaust fans with timer and/or thermostat control during the experiment. Fluorescent lighting was provided 24 hours per day. All poults were fed mash feeds ad libitumin hanging tube feeders and continuous access to drinking water via tank drinkers to 4 weeks and nipples thereafter.

\section{Experimental Diets}

The dietary formulation of the starter-grower feed was based on the NRC recommendation (National Research Council 1994) and included a corn-soybean control, a corn or wheat-based diets (Table 1). In the corn based soybean free diet, canola, lentils, chickpeas, corn gluten meal and fishmeal were used to increase protein and to supply a wider variety of amino acids because of the absence of soybean. In addition, corn oil replaced soybean oil as a fat source in the non-soybean diets.

\section{Measurements and Samples}

Starter-grower feed was weighed and recorded prior to distribution to each pen. During the experiment, poults were weighed individually at two, four, six, and eight weeks of age and feed 
consumption was determined on a per pen basis. Mortality and culled birds were recorded daily. Body weights and feed consumption was used in the calculation of feed conversion.

Table (1): Experimental Starter/Grower diets for turkey poults from 0-8 weeks.

\begin{tabular}{|c|c|c|c|}
\hline Ingredients & $\begin{array}{l}\text { Control } \\
\text { Corn/Soy }\end{array}$ & $\begin{array}{l}\text { Corn based } \\
\text { No Soybean } \\
\text { Meal }\end{array}$ & $\begin{array}{l}\text { Wheat Based } \\
\text { No corn or } \\
\text { soybean meal }\end{array}$ \\
\hline & \multicolumn{3}{|c|}{$\%$ of diet } \\
\hline Yellow Corn & 44.7 & 33.7 & - \\
\hline Wheat & - & - & 36.4 \\
\hline Soybean meal (44\%) & 42.7 & - & - \\
\hline Lentils & - & 6.0 & 5.0 \\
\hline Field Peas & - & 6.0 & 5.0 \\
\hline Canola Meal (36\%) & - & 34.0 & 31.2 \\
\hline Menhaden Fish Meal & 5.0 & 7.0 & 6.0 \\
\hline Soybean Oil & 1.5 & - & - \\
\hline Corn Oil & - & 4.0 & 5.0 \\
\hline Di-calcium Phosphate & 3.0 & 1.0 & 2.0 \\
\hline Limestone & 1.5 & 1.5 & 2.0 \\
\hline DL-Methionine & 0.5 & 0.5 & 0.5 \\
\hline Common Salt & 0.35 & 0.35 & 0.35 \\
\hline Vit-Min Premix* & 0.75 & 0.75 & 0.75 \\
\hline L-Lysine & - & 0.2 & 0.5 \\
\hline Total & 100.0 & 100.0 & 100.0 \\
\hline \multicolumn{4}{|c|}{ Calculated Analysis: (\% unless otherwise indicated) } \\
\hline $\mathrm{ME}(\mathrm{kcal} / \mathrm{kg}, \mathrm{DM})$ & 2,830 & 2,900 & 2,900 \\
\hline Crude Protein & 26.03 & 26.51 & 26.06 \\
\hline Crude Fiber & 2.69 & 4.63 & 4.46 \\
\hline Calcium & 1.59 & 1.39 & 1.59 \\
\hline Avail. Phosphorus & 0.89 & 0.59 & 0.61 \\
\hline Met & 0.95 & 1.00 & 0.98 \\
\hline TSAA & 1.32 & 1.32 & 1.31 \\
\hline Lys & 1.62 & 1.64 & 1.75 \\
\hline Arg & 1.85 & 1.28 & 1.21 \\
\hline Try & 1.07 & 0.70 & 0.73 \\
\hline Thr & 1.05 & 0.95 & 0.92 \\
\hline $\operatorname{Trp}$ & 0.38 & 0.23 & 0.24 \\
\hline Ile & 1.18 & 0.93 & 0.93 \\
\hline
\end{tabular}

\section{Statistical Analysis}

Bodyweights were subjected to one way analysis of variance (ANOVA) testing, using the R-studio software package for windows (Development Core Team 2008). Treatment means were compared using the least significant difference (LSD) test. The chosen level of significance was $\mathrm{P} \leq 0.05$. Feed conversion rates were calculated on a per pen basis with treatment means compared using Duncan's Multiple Range test.

\section{RESULTS AND DISCUSSION}

Throughout the experiment, mean body weights of poults fed the control diet were significantly higher $(\mathrm{P}>0.05)$ than those fed either the corn based-soybean free and wheat based corn-soybean free diets at 
2,4,6, and 8 weeks of age (Table 2). Mean body weights of the poults fed either alternative diet were not different at the various ages.

Table (2): Effect of excluding soybean alone or corn and soybean from diets for turkey poults on mean body weights (kg) at 2, 4, 6 and 8 weeks of age and mortality (Day-one to 8 Weeks of age).

\begin{tabular}{|c|c|c|c|c|c|}
\hline \multirow[b]{2}{*}{ Diet } & \multicolumn{4}{|c|}{ Weeks of Age Mortality } & \\
\hline & 2 & 4 & 6 & 8 & \\
\hline Control (Corn/soybean) & $0.32^{\mathrm{a}}$ & $1.05^{\mathrm{a}}$ & $2.34^{\mathrm{a}}$ & $4.08^{\mathrm{a}}$ & $7 \%$ \\
\hline Corn based (Corn/No soybean) & $0.22^{b}$ & $0.73^{b}$ & $1.66^{\mathrm{b}}$ & $3.10^{\mathrm{b}}$ & $14 \%$ \\
\hline Wheat-based (No corn/No soybean) & $0.24^{\mathrm{b}}$ & $0.77^{\mathrm{b}}$ & $1.82^{\mathrm{b}}$ & $3.22^{b}$ & $13 \%$ \\
\hline
\end{tabular}

${ }^{a b}$ Treatment means in columns with different superscripts are significantly different $(P<.05)$.

Final body weights of poults fed the control diet were significantly higher than those fed a corn or wheat - corn-soybean free diets. A similar bodyweight response was reported by Payvastagan et al. (2012) in broilers when $20 \%$ canola meal was added to the diets as a replacement for soybean meal. Hameed et al. (2002) reported similar results when Japanese quail diets contained more than 15\% canola. In addition, Sarcicek et al. (2005) reported that canola meal can be used as a replacement of soybean meal at level of $25 \%$ in quail rations without detrimental effects on their body weights.

In this study, there was no significant difference between the mean body weights of birds fed the corn or wheat based, corn-soybean free diets to eight weeks of age, 3.1 and $3.2 \mathrm{~kg}$, respectively. It was also found that mortality of the poults fed soybean free diets was twice as high as poults receiving the control diet. This indicates that excluding soybean alone or in the combination with corn from diets of turkey poults can have a negative effect on poult performance.

No significant differences in feed efficiency $(P>0.05)$ between the three experimental treatments were observed with feed conversions of $1.84,1.83$, and, 1.76 respectively (Table 3 ). These results are contrary to those of Payvastagan et al. (2012), who reported $20 \%$ inclusion of canola meal as a replacement for soybean meal in broiler diets significantly impaired the feed conversion ratio.

Table (3): Effect of diets that exclude soybean alone or in combination with corn on poult feed conversion from day 0 to 8 wks of age.

\begin{tabular}{lcccc}
\hline Treatment & \multicolumn{3}{c}{ Replicate ( $\mathrm{n}=13$ per replicate \& group)Overall } & \multirow{2}{*}{ Mean } \\
\cline { 2 - 4 } & 1 & 2 & 3 & 1.76 \\
\hline Control (Corn/soybean) & 1.78 & 1.71 & 1.8 & 1.84 \\
Corn based (Corn/No soybean) & $2.81^{*}$ & 1.87 & 1.81 & 1.83 \\
Wheat based (No corn/No soybean) & 1.85 & 1.77 & 1.89 & \\
\hline
\end{tabular}

${ }^{*}$ Treatment feed data was excluded from the statistical analysis due to excessive feed wastage.

No Significance

When soybean meal was completely removed from the diet, growth rate was reduced. Alternative feed ingredients such as lentils, field peas, chickpea, and canola can partially replace soybean meal in the diets which may be desirable for small producers of organic turkeys, however, soybean free diets with corn or wheat did not support optimal growth. More research is needed to identify combinations of alternative grains and possibly their contributions of amino acids that will support proper growth and production in organically fed poults.

\section{CONCLUSIONS}

Substituting all of the soybean and/or corn with lentils and field peas, in turkey poult diets results in significantly lower body weights at 8 weeks of age. Feed conversion was not significantly affected by the lack of soybean and/or corn in the diets of poults up to 8 weeks of age. 


\section{ACKNOWLEDGMENTS}

Very special appreciation is expressed to the Iraqi Federal Government and the Higher Committee for Education development in Iraq for funding this study.

\section{REFERENCES}

Aeschbacher, K., R. Messikommer, L. Meile and C. Wenk (2005). Bt176 corn in poultry nutrition: physiological characteristics and fate of recombinant plant DNA in chickens. Poult. Sci, 84(3), 385394.

Akmal Khan, M., I. A. Rana, I. Ullah and S. Jaffery (1987). Physicochemical characters and nutrient composition of some improved lines of lentils grown in Pakistan. Journal of Food Composition and Analysis, 1(1), 65-70.

Algam, T. A., K. A. A. Atti, B. M. Dousa, S. M. Elawad and B. A. Elmanan (2013). Effect of dietary raw chickpea (Cicerarietinum L.) seeds replacement groundnut meal, sesame meal on broiler performance and blood constituents. Online Journal of Animal and Feed Research (OJAFR), 3(2), 91-95.

Algam, T. A., K. A. A. Atti, B. M. Dousa, S. M. Elawad and A. F. Elseed (2012). Effect of dietary raw chick pea (Cicerarietinum L.) seeds on broiler performance and blood constituents. International Journal of Poult. Sci., 11(4), 294-297.

Cromwell, G. L., M. D. Lindemann, J. H. Randolph, G. R. Parker, R. D. Coffey, K. M. Laurent and G. F. Hartnell (2002). Soybean meal from roundup ready or conventional soybeans in diets for growingfinishing swine. Journal of Animal Science, 80(3), 708-715.

Development Core Team (2008). R: A language and environment for statistical computing. R Foundation for Statistical Computing, Vienna, Austria. ISBN 3-900051-07-0, URL http://www.R-project.org.

GMO Compass (2010). Genetically modified plants: Global cultivation area. Retrieved from http://www.gmo-compass.org /eng/agri_biotechnology/gmo_planting/342 genetically_modified_soybean_global_area_under_cultivation.html.

Hameed, S., N. Ahmad and M. Rabbani (2002). Effect of replacing dietary levels of soybean meal with canola meal in Japanese quail. International Journal of Agriculture and Biology, 4(3), 389-391.

Jennings, J. C., D. C. Kolwyck, S. B. Kays, A. J. Whetsell, J. B. Surber, G. L. Cromwell and K. C. Glenn (2003). Determining whether transgenic and endogenous plant DNA and transgenic protein are detectable in muscle from swine fed Roundup Ready soybean meal. Journal of Animal Science, 81(6), $1447-1455$.

Key, S., J.K.C. Ma and P.M. Drake (2008). Genetically modified plants and human health. Journal of the Royal Society of Medicine, 101(6), 290-298.

Kruft, D. (2001). Impacts of Genetically-Modified Crops and Seeds on Farmers. Retrieved from http://law.psu.edu/_file/aglaw/Impacts_of_Genetically_Modified.pdf.

Leu, A. (2012). GMO Safety Issues based on Science. Retrieved from http://www.ofa.org.au/pages/GMO-Safety-Issues-based-on-Science.html.

National Corn Growers Association. (2012). World of Corn. Retrieved from www.ncga.com.

National Research Council. (1994). Nutrient Requirements of Poultry. 9th revised edition. National Academy Press, Washington, DC.

Nordlee, J. A., S. L. Taylor, J. A. Townsend, L. A. Thomas and R. K. Bush (1996). Identification of a Brazil-nut allergen in transgenic soybeans. New England Journal of Medicine, 334(11), 688-692.

Payvastagan, S., P. Farhoomand, R. Shahrooze, N. Delfani and A. Talatapeh1 (2012). The effects of different levels of canola meal and copper on performance, susceptibility to ascites and plasma enzyme activities in broiler chickens. Annals of Biological Research, 3(11), 5252-5258. 


\section{Sulaiman and Hermes}

Sarcicek, B. Z., U. Klc and A. V. Garipoglu (2005). Replacing soybean meal (SBM) by canola meal $(\mathrm{CM})$ : The effects of multi-enzyme and phytase supplementation on the performance of growing and laying quails. Asian Australian Journal of Animal Sciences, 18(10), 1457-1463.

Spragg, J. and R. Mailer (2007). Canola meal value chain quality improvement. Pork Cooperative Research Centre. Retrieved from http://www.cabdirect.org/abstracts/20103063915.html

Swanson, N. (2013). Genetically Modified Organisms and the deterioration of health in the United States. Retrieved from http://people.csail.mit.edu/seneff/glyphosate/NancySwanson.pdf.

Taylor, M. L., G. F. Hartnell, S. G. Riordan, M. A. Nemeth, K. Karunanandaa, B. George and J. D. Astwood (2003). Comparison of broiler performance when fed diets containing grain from roundup ready (NK603), yieldgard $x$ roundup ready (MON810 x NK603), non-transgenic control, or commercial corn. Poult. Sci., 82(3), 443-453.

Taylor, M., D. Lucas, M. Nemeth, S. Davis and G. Hartnell (2007). Comparison of broiler performance and carcass parameters when fed diets containing combined trait insect-protected and glyphosatetolerant corn (MON 89034\$ltimes\$ NK603), control, or conventional reference corn. Poult. Sci, 86(9), 1988-1994.

Torki, M. and A. Karimi. (2007). Evaluation of dietary replacement of soybean meal by chickpea supplemented by enzymes on performance of broiler chicks. World Poultry Science Association, Proceedings of the 16th European Symposium on Poultry Nutrition 651-654.

United States Department of Agriculture. (2013). Adoption of Genetically Engineered Crops in the U.S. Retrieved from http://www.ers.usda.gov/data-products/adoption-of-genetically-engineered-crops-inthe-us/recent-trends-in-ge-adoption.aspx\#.UoAoduJjHW0.

Vecchio, L., B. Cisterna, M. Malatesta, T. E. Martin and M. Biggiogera (2009). Ultrastructural analysis of testes from mice fed on genetically modified soybean. European Journal of Histochemistry, 48(4), $449-454$. 
تأثثر عليقة خالية من فول الصويا والذرة على أداء الديك الرومي من اليوم الاول إلى ثمانية أسابيع من العمر

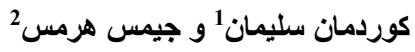 \\ لقسم الانتاج الحيوانس، جامعة دوهوك، دوهوك، العراق. \\ 2قسم علوم الحيوان و المراعى، جامعة ولاية اوريجون، كورفالس، أوريجون، الولايات المتحدة الأمريكية.
}

في السنوات الأخيرة، اهتم منتجو الدواجن بإيجاد بدائل للارة و مسحوق فول الصويا لعدة أسباب. تعتبر المخاوف الصحية المتعلقة

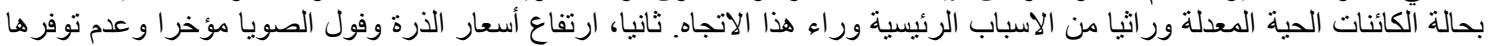

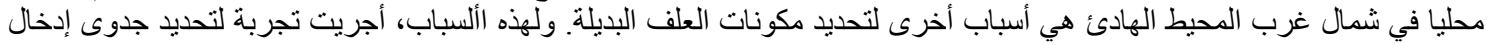

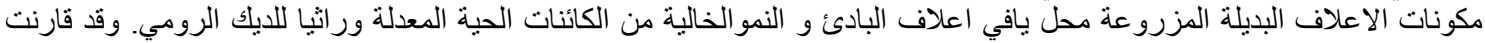

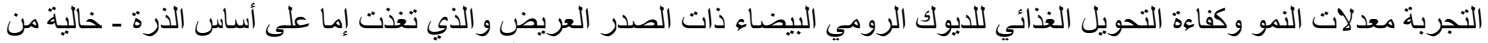

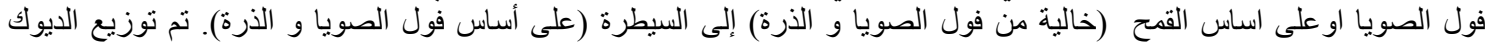

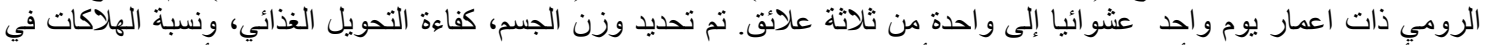

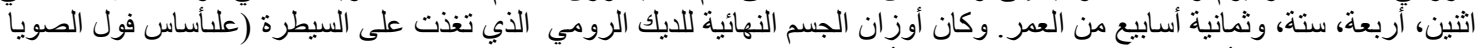

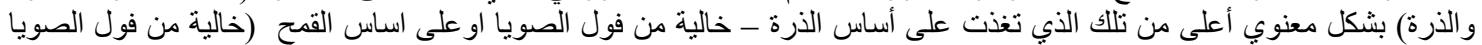

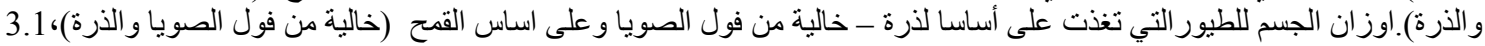

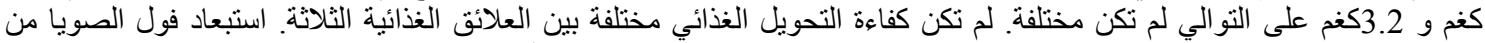
العليقة ادى الى انخفاض معدل النمو في الديك الرومي ولكن لم يؤثر على كفاءة تحويل الأعلاف. لكافل 